\title{
Empiric mathematical model for predicting the content of alpha-acids in hop (Humulus lupulus L.) cv. Aurora
}

\author{
Siniša Srečec ${ }^{1 *}$, Barbara Čeh ${ }^{2}$, Tanja Savić Ciler ${ }^{1}$ and Alenka Ferlež Rus ${ }^{2}$
}

\begin{abstract}
The aim of this research is to find a simple mathematical model due to sum of effective temperatures and rainfalls from second germination after spring pruning till the technological maturity of hop cones, in order to achieve reliable prognosis of alpha-acids content in hop cv. Aurora. After mathematical analyses of experimental data by Eurequa Formulize 0.96 Beta software 17 equations were offered, and after substituting the values of dependent and independent variables in all equations only one equation was chosen with $p=0.034(p<0.05)$. This equation is not reliable in extremely drought year if crop evapotranspiration $E T_{0}$ in July is higher than 4.5, primarily because of negative influence on formation and development of hop glandular trichomes. Considering achieved results it is possible to suggest following general equation for alpha-acids accumulation in hop: $y=\left[\left(k_{1} w\right)-k_{2}-\left(k_{3} w^{2}\right) / x\right] \div(-10) \leftrightarrow E T_{0}$ suly $\leq 4.5$. Where $y$ is alpha acids content in dry matter (\%), $x=$ sum of effective temperatures and $w=$ sum of rainfals, both from second germination after spring pruning till technological maturity of hop cones. Coefficients $k_{1}, k_{2}$ and $k_{3}$ are determined for cultivar Aurora (53.8, 453 and 1.33, respectively).
\end{abstract}

Keywords: Hop, Humulus lupulus L, Alpha-acids, Accumulation of alpha-acids, Empiric mathematical model, Eurequa software

\section{Introduction}

The alpha-acids are important quality parameter in the hop industry since their production significantly defines the global hop supply statistics (Pavlovic et al. 2008). The biosynthesis of hop secondary metabolites is divided into three biosynthetic pathways A, B and $\mathrm{C}$, and biosynthesis of humulone or alpha-acids is the final step of C pathway (Nagel et al. 2008; Wang et al. 2008). Accumulation of alpha acids is most intensive in third and fourth week after hop flowering (Wang et al. 2008). Mozny et al. (2009) found a positive impact of rainfall and a negative effect of temperature on alpha-acids accumulation in Czech Saaz hop cultivar, as well as Srečec et al. 2008 in Aurora hop cultivar. On the other hand, Kučera and Krofta (2009) found that the strongest impact on the alpha-acid content was exerted by air temperatures in

\footnotetext{
* Correspondence: ssrecec@vguk.hr

${ }^{1}$ Križevci College of Agriculture, M. Demerca 1, HR-48260, Križevci, Croatia

Full list of author information is available at the end of the article
}

July and rainfall had significant effects during the period from May to July, while in August the impact of a rainfall was negligible. Pavlovič et al. (2012) found that the impact of weather parameters on the alpha-acids in hops can be linked with the emergence of certain phases of recorded phenomena in the plants, which do not coincide in time with the dispensation of each month. Generative bodies in the cultivar Aurora begin to develop in the second half of June (week 26), and the plant is in full blooming by the mid July (week 28). These results stays in line with results of Srečec et al. (2008) who found significant decrease of alpha-acids accumulation if average daily reference crop evapotranspiration in June is higher or equal to 4.5. Srečec et al. (2008) on the basis of results of linear and multiple correlations suggested a following functional equation for accumulation of alpha acids (equation 1).

\section{实}

C 2013 Srečec et al., Licensee Springer. This is an Open Access article distributed under the terms of the Creative Commons Attribution License (http://creativecommons.org/licenses/by/2.0), which permits unrestricted use, distribution, and reproduction in any medium, provided the original work is properly cited. 


$$
\begin{aligned}
A= & f(T ; R ; I) \rightarrow A[7.41 ; 12.35] \\
= & f\left(T\left(\sum_{F 3}^{F 9}[1601.74 ; 2000]\right) ;\right. \\
& R\left(\sum_{F 3}^{F 9}[212.1 ; 391.8]\right) ; \\
& \left.I\left(\sum_{F 3}^{F 9}[1027.23 ; 1229.61]\right)\right) \leftrightarrow E T_{0(V I I)} \leq 4.5
\end{aligned}
$$

where:

- A - content of alpha-acids in dry matter (\%)

- $T$ - sum of effective temperatures from second germination to hop harvest $\left({ }^{\circ} \mathrm{C}\right)$

- I - total hours of sun shining from second germination to hop harvest

- F3 - second germination after pruning

- F9 - technological maturity of hop cones (harvest time)

- $E T_{O(V I I)}$ - average daily reference crop evapotranspiration in July $\left(\mathrm{mm} \mathrm{day}^{-1}\right)$
This equation, based on significant analytical data, unfortunately does not allow reliable prognosis of alphaacids accumulation in technological maturity of hop cones.

However, nowadays because of very high hop supply, prognosis of alpha-acids accumulation become very important in order to estimate the commodities. Thus, the aim of this research is to find a simple mathematical model due to sum of effective temperatures and rainfall from second germination after spring pruning till the technological maturity of hop cones, in order to achieve reliable prognosis of alpha-acids accumulation in hop cv. Aurora.

\section{Materials and methods}

Research was carried out on hop cv. Aurora planted in hop garden in Croatia, near the village of Gregurovec (close to Križevci), during the six vegetation years (2001 2006, Srečec et al. 2008). The soil type of examined hop garden is an eutric pseudogley or eutric podzoluvisol. Content of physiological active phosphorus and potash, analysed by the AL-method, was medium. Average content of $\mathrm{P}_{2} \mathrm{O}_{5}$ and $\mathrm{K}_{2} \mathrm{O}$ during the all six

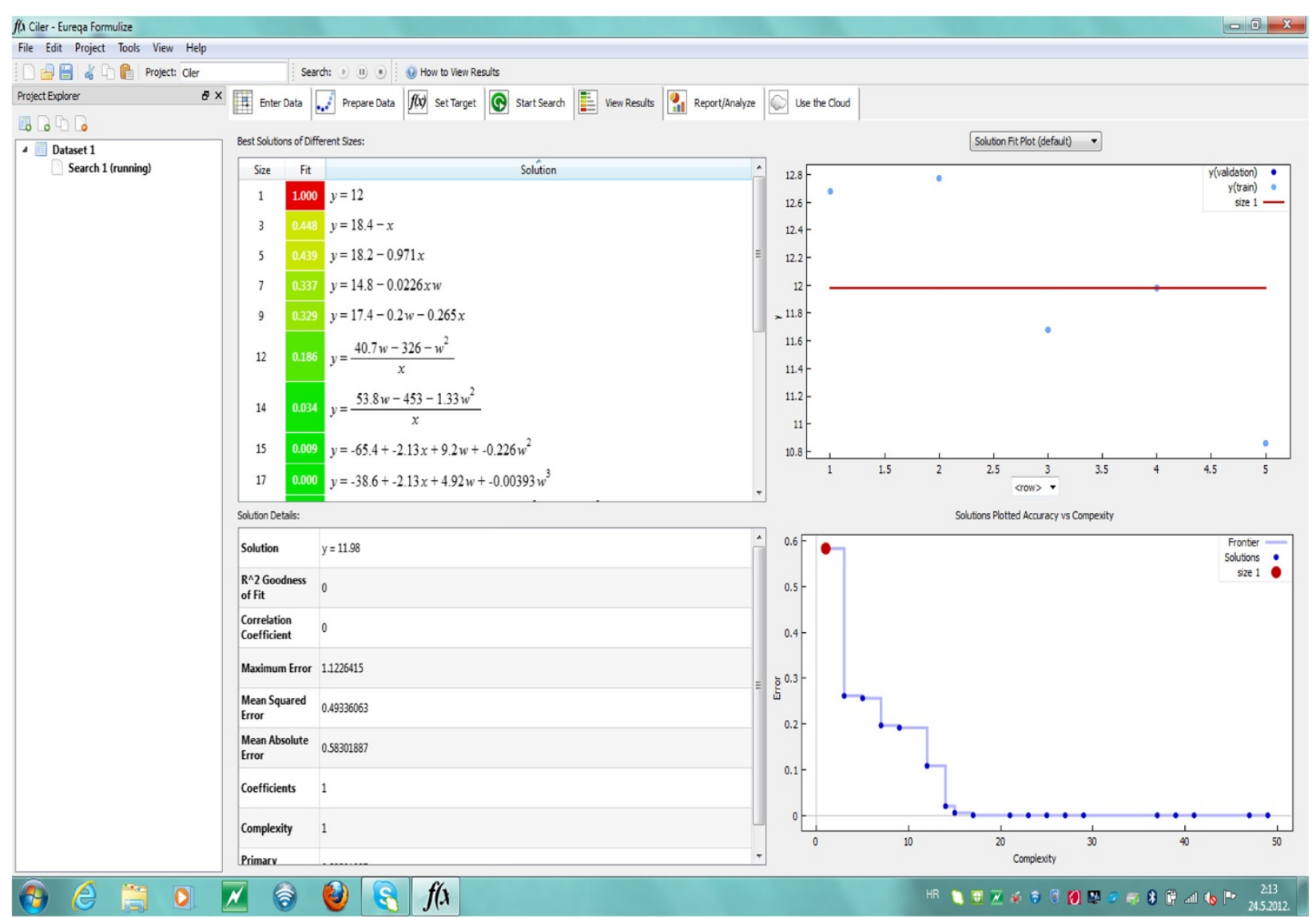

Figure 1 Menu of Eurequa Formulize 0.96 on which is visible workflow (computing) with suggested equations and their error probabilities. 
Table 1 Reliability of mathematical model for accumulation of alpha-acids in hop cultivar Aurora in location of Gregurovec, Croatia during the six vegetation periods (2001-2006*)

\begin{tabular}{ccccccc}
\hline Crop year & $\begin{array}{c}\text { Sum of effective } \\
\text { temperatures }\left({ }^{\circ} \mathbf{C}\right)\end{array}$ & $\begin{array}{c}\text { Sum of total } \\
\text { rainfalls }(\mathbf{m m})\end{array}$ & $\begin{array}{c}E T_{o} \text { in } \\
\text { July }\end{array}$ & $\begin{array}{c}\text { Calculated content of alpha- } \\
\text { acids (\%) in dry matter }\end{array}$ & $\begin{array}{c}\text { Analysed content of alpha- } \\
\text { acids (\%) in dry matter (mean) }\end{array}$ & $\begin{array}{c}\text { Difference (alpha } \\
\text { calc. - alpha analysed) }\end{array}$ \\
\hline 2001 & 1698.4 & 393.7 & 4.26 & 10.9 & 11.6 & 0.7 \\
2002 & 1932.1 & 425.8 & 4.20 & 11.3 & 6.7 & 0.2 \\
2003 & 1994,4 & 175.2 & 5.5 & 2.5 & 10.0 & $-4.2(\mathrm{n} / \mathrm{r})$ \\
2004 & 1856.7 & 398.5 & 4.28 & 10.2 & 9.7 & 0.2 \\
2005 & 1920.8 & 403.3 & 4.38 & 10.1 & 9.3 & 0.5 \\
2006 & 1872.1 & 382.0 & 4.42 & 9.2 & 0.1 \\
\hline
\end{tabular}

* previous functional equation for accumulation of alpha acids based on the results of linear and multiple correlations between weather conditions and accumulation of alpha acids described by Srečec et al. $2008 \mathrm{n} / \mathrm{r}$ - not reliable.

experimental years was 19.1 and $15.4 \mathrm{mg}$ per 100 grams of soil, respectively. Content of humus in soil was very low, only $1.48 \%$. Fertilization was provided on the basis of plant uptake for phosphorus and potash and in three splits of nitrogen $\left(50+70+50 \mathrm{~kg} / \mathrm{ha} \mathrm{N}\right.$ on $20^{\text {th }}$ May, $10^{\text {th }}$ June and $5^{\text {th }}$ July) in all 6 experimental years. Meteorological data in Croatia were collected in Agro Meteorology Station in Križevci, placed five kilometres far away from the hop garden.

Hop cones were sampled from the same plants each year in the phenological phase of technological maturity.

The empiric mathematical equation achieved in Croatia was checked in year of 2012 at the same cultivar grown in completely different agro-ecological conditions in Žalec, Slovenia. $\mathrm{P}_{2} \mathrm{O}_{5}$ and $\mathrm{K}_{2} \mathrm{O}$ in the hop garden was 46.0 and $20.1 \mathrm{mg}$ per 100 grams of soil, respectively. Content of humus in soil was $2.9 \%$. The soil is middle heavy, young alluvial soil, poorly developed on sandy-gravelly deposits of two rivers.

Meteorological data in Slovenia for year 2012 were collected in Agro Meteorology Station at the Slovenian Institute of Hop Research and Brewing placed near by the hop garden.

Sum of effective temperatures, during the hop vegetation, for every experimental year, was calculated by the following equation (2):

$$
\Sigma_{\text {effective temperaturs }}=\frac{D \min T+D \max T}{2}-5^{\circ} \mathrm{C}
$$

where:

DminT - daily minimal temperature,

Dmax T - daily maximal temperature and $5^{\circ} \mathrm{C}$ is minimal temperature required for beginning of hop vegetation.

The content of alpha-acids was determined by the method of lead conductance value of hops, powder and pellets prescribed by Analytica - EBC 7.4 (Anon. 1998) and dry matter content by the method of moisture content of hops and hop products prescribed by Analytica - EBC 7.2 (Anon. 1998). The boarder of repeatability $\left(r_{95}\right)$ for method of lead conductance value is 0.2 and the boarder for reproducibility $\left(R_{95}\right)$ is1.

During the examined vegetation years in Croatia, samples of hop cones were handpicked and analysed from the same 35 plants, randomly chosen and marked in the first research year of 2001 (Srečec et al. 2008) in the same hop garden, which means five control plots with seven plants per each plot within the same hop garden. On the other hand, samples of hop cones in Slovenia in year of 2012 were also handpicked, but sampled randomly from different plants in the same hop garden.

Analyses of achieved analytical results were provided by software Eureqa Formulize 0.96 Beta (Nutonian, Inc.). Eureqa Formulize is a scientific data mining software package that searches for mathematical patterns hidden in data. Formulize's user interface is organized as a set of seven tabs that correspond to the normal workflow through the program, and user guide is organized around those tabs (see: http://www.nutonian.com). In mathematical analyses of experimental data sum of effective temperatures and total rainfall were treated as independent variables (marked as $x$ and $w$ variables) and content of alpha-acids (\%) as dependent variable (y variable).

Table 2 Reliability of mathematical model for accumulation of alpha-acids in hop cultivar Aurora in location of Žalec, Slovenia in 2012

\begin{tabular}{|c|c|c|c|c|c|c|}
\hline Crop year & $\begin{array}{l}\text { Sum of effective } \\
\text { temperatures }\left({ }^{\circ} \mathrm{C}\right)\end{array}$ & $\begin{array}{l}\text { Sum of total } \\
\text { rainfalls ( } \mathrm{mm})\end{array}$ & $\begin{array}{l}E T_{0} \text { in } \\
\text { July }\end{array}$ & $\begin{array}{l}\text { Calculated content of alpha- } \\
\text { acids (\%) in dry matter (mean) }\end{array}$ & $\begin{array}{l}\text { Detected content of alpha- } \\
\text { acids (\%) in dry matter (mean) }\end{array}$ & $\begin{array}{c}\text { Difference (alpha } \\
\text { calc. - alpha detect.) }\end{array}$ \\
\hline 2012 & 1766.2 & 400.4 & 4.2 & 10.8 & 10.2 & 0.6 \\
\hline
\end{tabular}




\section{Results and discussion}

After mathematical analyses of experimental data by Eureqa Formulize 0.96 Beta software 17 equations were offered (Figure 1).

After substituting the values of dependent and independent variables in all equations only one equation was chosen with $\mathrm{p}=0.034(\mathrm{p}<0.05)$ (equation 3$)$.

$$
y=\frac{53.8 w-453-1.33 w^{2}}{x}
$$

Where:

$y$ - alpha-acids content in dry matter (\%)

$x$ - sum of effective temperatures $\left({ }^{\circ} \mathrm{C}\right)$ from second

germination after the spring pruning till technological maturity

$w$ - sum of total raifalls $(\mathrm{mm})$ for the same period

However, that equation had to be refined by the authors, due to the negative results obtained and shifting the decimal point one space to the left (equation 4), because fraction must be divided by -10 in order to achieve reliable values.

$$
y=\frac{53.8 w-453-1.33 w^{2}}{x} \div(-10)
$$

Reliability of equation (4) was checked by inserting the values for the dependent and independent variables for the ten-year period for Croatian agro-ecological conditions (Table 1).

The results were tested also in agro-ecological conditions of Žalec, Slovenia during the 2012 (Table 2).

It is obvious that the differences between calculated and detected content of alpha-acids varied from 0.1 to 0.7 , which is within boarders of repeatability $\left(r_{95}=0.2\right)$ and reproducibility $\left(\mathrm{R}_{95}=1\right)$ for EBC 7.4 method (Anon 1998). However, this equation is not reliable in extremely drought year, like the year of 2003 was. That confirms results of Srečec et al. (2008), who found a negative correlation, determined by Spearman's rank correlation, during the phonological phase of hop cones formation, between average daily reference crop evapotranspiration $\left(\mathrm{ET}_{0}\right)$ in July and yield of hop cones, $\mathrm{r}_{s}=-0.75$ $(\mathrm{p}<0.05)$, as well as between $\mathrm{ET}_{0}$ and yield of alphaacids in the same period, $\mathrm{r}_{s}=-0.88(\mathrm{p}<0.05)$. This is also possible to explain with results of Pavlovič et al. (2012), according to them, rainfall quantity from June 18 to July 22 shows the highest correlation with alpha-acid contents and impact of rainfall begins to decline after July 29. However, in time after July 29, the formation of glandular trichomes starts and the positive Spearman's rank correlations were found between the average number of glandular trichomes and the content of alpha-acids $\left(\mathrm{r}_{s}=0.90 ; \mathrm{p}<0.05\right)$ and also between the average volume of glandular trichomes and content of alpha-acids $\left(\mathrm{r}_{s}=0.97 ; \mathrm{p}<0.05\right)$ (Srečec et al. 2011).

Finally, considering these results it is possible to suggest following general equation for alpha-acids accumulation in hop cv. Aurora (equation 5):

$$
y=\frac{\left(k_{1} w\right)-k_{2}-\left(k_{3} w^{2}\right)}{x} \div(-10) \leftrightarrow E T_{0(J u l y)} \leq 4.5
$$

In case of Aurora hop cultivar coefficients $k_{1}, k_{2}$ and $k_{3}$ are determined, which have to be determined for the other hop cultivars.

\section{Conclusion}

Achieved results confirms the results of Srečec et al. (2008) and using the Eureqa Formulize 0.96 Beta software allows reliable mathematical analyses but only if linear and multiple correlations of experimental data are previously provided. However, these results as well as results of previous authors show that weather conditions, during the hop vegetation have a stronger influence on accumulation of alpha-acids in technological maturity of hop cones than soil conditions.

\section{Competing interests}

The authors declare that they have no competing interests.

\section{Authors' contribution}

SS conducted the research and led the writing, BČ checked equation (4) in Slovenia during hop growing year of 2012, TSC assisted in research, AFR coordinated the field work in Slovenia during hop growing year of 2012. All authors read and approved the final manuscript.

\section{Author details}

${ }^{1}$ Križevci College of Agriculture, M. Demerca 1, HR-48260, Križevci, Croatia. ${ }^{2}$ Slovenian Institute of Hop Research and Brewing, Cesta Žalskega tabora 2, Žalec SI-3310, Slovenia.

Received: 5 November 2012 Accepted: 6 February 2013 Published: 19 February 2013

\section{References}

Anon (1998) Analytica - EBC. Issued by EBC Analysis Committee. Verlag Hans Getränke Fachverlag, Nurnmberg

Kučera M, Krofta K (2009) Mathematical model for prediction of yield and alpha acid contents from meteorological data for Saaz aroma variety. Acta Horticulturae 848:131-139

Mozny M, Tolasz R, Nekovar J, Sparks T, Trnka M, Zalud Z (2009) The impact of climate change on the yield and quality of Saaz hops in the Czech Republic. Agr Forest Meteorol 149:913-919

Nagel J, Culley LK, Lu Y, Liu E, Matthews PD, Stevens JF, Page JE (2008) EST analysis of hop glandular trichomes identifies an O-methyltransferase that catalyzes the biosynthesis of xanthohumol. Plant Cell 20:180-200

Pavlovic M, Koumboulis FN, Tzamtzi MP, Rozman C (2008) Role of automation agents in agribusiness decision support systems. Agrosciencia 42:913-923

Pavlovič V, Pavlovič M, Čerenak A, Košir IJ, Čeh B, Rozman Č, Turk J, Pazek K, Krofta K, Gregorič G (2012) Environment and weather influence on quality and market value of hops. Plant Soil Environ 58:155-160

Srečec S, Kvaternjak I, Kaučic D, Špoljar A, Erhatić R (2008) Influence of climatic conditions on accumulation of alpha-acids in hop cones. Agriculturae Conspectus Scientificus 73:161-166 
